\title{
Pengaruh Lama Waktu Fermentasi Akhir (Final Proofing) Terhadap Kualitas Japanese Milk Bread
}

\author{
Septo Adi Prabowo ${ }^{1, \text { a) }}$, Guspri Devi Artanti ${ }^{2, b)}$, Efrina $^{3, c)}$ \\ ${ }^{1,2,3}$ Program Studi Pendidikan Tata Boga, Universitas Negeri Jakarta, Jalan Rawamangun Muka,
} DKI Jakarta, 13220

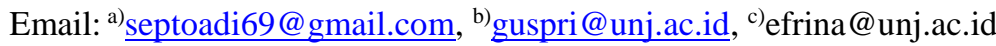

\begin{abstract}
The objective of this study was to analysis the effect of the final proofing time $(50,60 \& 70$ minutes) on the making of Japanese Milk Bread. This research was conducted at the Pastry \& Bakery Laboratory of Culinary Art Education Program, State University of Jakarta using the experimental method. Quality assessment was carried out on moderately trained panellists, namely 45 students of the Culinary Art Education Program, State University of Jakarta. The best quality test results on the external aspect: the form aspect is the final proofing of 70 minutes is in the very expanding category; for aspects of skin colour and characteristics of the skin crust, the final proofing of 50,60, and 70 minutes was in the yellowish white category and was close to thin. Meanwhile, the best quality assessment for internal aspects, pore aspects, crumb colour and taste, the third final proofing was 50,60, and 70 minutes with the assessment categories approaching smooth, yellowish white and milky taste; the texture aspect of the fermentation at the end of 60 minutes is in the very soft category; aspect of fermented aroma at the end of 70 minutes with a butter scented assessment category. The best high dimensional aspect physical test at the final proofing of the final proofing is 60 minutes with a height of $6 \mathrm{~cm}$; the pore aspect of fermentation at the end of 70 minutes still has small and fine pores and has no air space in the bread. The Kruskal-Wallis test results with $\alpha=0.05$ indicate that there is no effect of the final proofing time on the quality of Japanese Milk Bread. Based on the quality and physical test results, the researchers recommended the final proofing time of 70 minutes as the best time.
\end{abstract}

Key words: japanese milk bread, final fermentation time, quality

\begin{abstract}
Abstrak
Penelitian ini bertujuan untuk mempelajari pengaruh lama waktu fermentasi akhir (50, 60 \& 70 menit) pada pembuatan Japanese Milk Bread. Penelitian ini dilakukan di Laboratorium Pastry \& Bakery Program Studi Pendidikan Tata Boga, Universitas Negeri Jakarta dengan menggunakan metode eksperimen. Penilaian kualitas dilakukan kepada panelis agak terlatih yaitu mahasiswa Program Studi Pendidikan Tata Boga, Universitas Negeri Jakarta yang berjumlah 45 orang. Hasil uji kualitas terbaik pada aspek eksternal: aspek bentuk adalah fermentasi akhir 70 menit berada pada kategori sangat mengembang; untuk aspek warna kulit dan karakteristik kerak kulit ketiga fermentasi akhir 50, 60, dan 70 menit berada pada kategori putih kekuningan dan mendekati tipis. Sementara penilaian kualitas terbaik untuk aspek internal, aspek pori, warna remah dan rasa ketiga fermentasi akhir 50, 60, dan 70 menit dengan kategori penilaian mendekati halus, putih kekuningan dan terasa susu; aspek tekstur fermentasi akhir 60 menit berada pada kategori sangat lembut; aspek aroma fermentasi akhir 70 menit dengan kategori penilaian beraroma butter. Uji fisik aspek dimensi tinggi terbaik pada fermentasi akhir fermentasi akhir 60 menit dengan tinggi $6 \mathrm{~cm}$; aspek pori fermentasi akhir 70 menit masih mempunyai pori yang kecil dan halus serta tidak mempunyai ruang udara didalam roti. Hasil uji Kruskal-Wallis dengan $\alpha=0,05$ menunjukkan bahwa tidak terdapat pengaruh lama fermentasi akhir terhadap kualitas Japanese Milk Bread. Berdasarkan hasil uji kualitas dan fisik peneliti merekomendasikan waktu fermentasi akhir 70 menit sebagai waktu terbaik.
\end{abstract}

Kata kunci: Japanese Milk Bread, waktu fermentasi akhir, kualitas 


\section{PENDAHULUAN}

Roti merupakan makanan yang terbuat dari tepung terigu atau tepung lainnya yang diragikan lalu dipanggang (Koswara, 2009). Terdapat 2 jenis roti yaitu roti manis dan roti tawar (Cahyana dan Artanti, 2015). Prinsip dasar teknik pembuatan roti adalah straight dough, sponge and dough, dan no time dough. Namun dengan berkembangnya inovasi produk roti maka berbagai produk baru dihasilkan, diantaranya Japanese Milk Bread.

Japanese Milk Bread adalah modifikasi dari produk roti manis yang dibentuk dengan cetakan muffin, berbentuk seperti cangkir dengan toping vla vanilla yang melingkari roti bertekstur lembut, berwarna remah putih kekuningan dan berasa gurih susu. Selama ini Japanese Milk Bread belum diketahui cara pembuatannya. Diduga Japanese Milk Bread menggunakan teknik straight dough yang ditambahkan dengan tangzhong untuk menghasilkan tekstur yang lebih lembut. Hal ini sesuai dengan penelitian yang dilakukan oleh Mohammed (2018) dalam membuat bakpau yang lebih lembut dan halus dengan penambahan tangzhong. Tangzhong adalah pasta tepung yang dimasak dalam air atau susu yang digunakan untuk meningkatkan tekstur roti, membuatnya lembut dan halus,

Dalam proses pembuatan roti terdapat beberapa titik kritis yang mempengaruhi kualitas produk roti diantaranya proses pengolahan, proses fermentasi akhir, dan proses pemanggangan namun menurut Syarbini Husin (2016) titik kritis dalam produksi roti adalah final proofing. Final proofing / fermentasi akhir merupakan proses fermentasi atau pengembangan terakhir agar diperoleh adonan yang mengembang sempurna (Chan, 2008). Fermentasi adonan bertujuan menghasilkan produk berkualitas baik, pembentukan cita rasa pada roti serta mutu pengunyahan yang baik (Koswara, 2009). Baardseth dkk (2000) dalam penelitiannya juga mengatakan salah satu fase kritis dalam produksi roti Prancis adalah saat proses fermentasi. Dalam proses ini aktivasi ragi dan waktu fermentasi menentukan jumlah gas yang diproduksi dan tingkat ekspansi pada adonan (Peighambardoust dkk, 2010).

Faktor penentu yang mempengaruhi proses fermentasi akhir ada 3, yaitu suhu, kelembapan (RH), dan waktu agar proses fermentasi akhir terbentuk gas $\mathrm{CO}_{2}$ yang optimal dapat di lakukan dengan melakukan kontrol temperatur pada kisaran $35-38^{\circ} \mathrm{C}$, kelembaban relatif (RH) antara $80-85 \%$ dan membutuhkan waktu agar adonan mengembang 2x lipat (Syarbini Husin, 2013). Waktu fermentasi akhir (final proofing) tidak boleh terlalu lama ataupun terlalu cepat. Waktu fermentasi akhir yang terlalu cepat akan membuat bentuk roti tidak mengembang secara optimal serta tekstur tidak akan menjadi lembut, dan apabila waktu fermentasi yang terlalu lama akan terjadi over proofing yang mengakibatkan bentuk roti menjadi tidak kokoh serta rasa dan aroma menjadi asam. Berdasarkan hal tersebut, maka perlu dilakukan penelitian tentang pengaruh waktu fermentasi akhir terhadap kualitas Japanese Milk Bread.

\section{METODE PENELITIAN}

Penelitian pengaruh lama waktu final proofing terhadap kualitas produk roti dilakukan di Laboratorium Pengolahan Roti dan Kue Program Studi Pendidikan Tata Boga, Universitas Negeri Jakarta dari bulan Februari 2019. Penelitian dilakukan dengan menggunakan metode eksperimen untuk mengetahui teknik pembuatan Japanese Milk Bread dengan penambahan tangzhong dan mengetahui waktu final proofing terbaik terhadap kualitas Japanese Milk Bread. Pengujian kualitas dilakukan dengan uji analisis fisik dan organoleptik. Pada aspek eksternal meliputi bentuk, warna kulit, dan karakteristik kulit. Pada aspek internal meliputi pori, warna remah, tekstur, rasa dan aroma.

Bahan yang digunakan dalam penelitian ini antara lain tepung terigu protein tinggi, air, susu bubuk, ragi instan, gula pasir, garam, bread improver, emulsifier, telur, susu cair full cream, mentega. Alat yang digunakan dalam penelitian ini antara lain mixer, box proofer, oven, cooling rack, tray, cetakan muffin, spatula plastik, timbangan, mangkok, sendok, kuas, spatula kayu. Dalam penelitian ini teknik yang digunakan dalam pembuatan Japanese Milk Bread adalah straight dough dengan penambahan tangzhong. 


\section{HASIL DAN PEMBAHASAN}

\section{Pembuatan Japanese Milk Bread}

Pembuatan Japanese Milk Bread dimulai dengan persiapan bahan dan penimbangan bahan. Pada penimbangan bahan disiapkan butter, bahan kering, dan bahan cairan. Pengadukan pertama dengan speed 1 untuk bahan kering selama 2 menit, lalu pengadukan kedua dengan mencampurkan bahan cairan selama 5 menit dan dilanjutkan pengadukan ketiga dengan kenaikan speed menjadi 2 dengan waktu 30 menit. Setelah kalis masuk ke tahap fermentasi awal selama 20 menit lalu proses pemotongan dan penimbangan masing-masing berat 30 gram serta pembulatan dan tahap fermentasi lanjutan selama 10 menit. Adonan roti lalu diratakan, dibentuk bulat, dan dimasukkan kedalam loyang muffin yang sudah diolesi butter. Setelah loyang terisi penuh masukkan kedalam lemari proofing (proofing box) dengan waktu fermentasi akhir 50, 60, dan 70 menit. Adonan yang sudah sesuai dengan waktu fermentasi akhir yang telah ditentukan maka lanjut pada tahap pemanggangan dengan suhu atas $150^{\circ} \mathrm{C}$ suhu bawah $180^{\circ} \mathrm{C}$ selama 13 menit. Setelah itu keluarkan loyang dari oven lalu pindahkan roti ke cooling rack untuk didinginkan dan dikemas.

Berdasarkan percobaan yang telah dilakukan dalam penelitian, faktor-faktor yang menjadi perhatian sebagai berikut :

a. Penggunaan proofing box untuk mengontrol suhu dan kelembaban

b. Pengadukan setelah semua bahan tercampur semua selama 30 menit untuk menghasilkan adonan yang kalis.

c. Proses pembentukan (moulding) dilakukan dengan cepat agar didapat bentuk yang seragam

d. Suhu ruangan yang tidak panas agar tidak mempercepat proses fermentasi

\section{Uji Organoleptik}

Pada uji organoleptik, analisis yang dilakukan meliputi analisis aspek eksternal dan internal. Pada aspek eksternal, meliputi bentuk, warna kulit, dan karakteristik kulit.

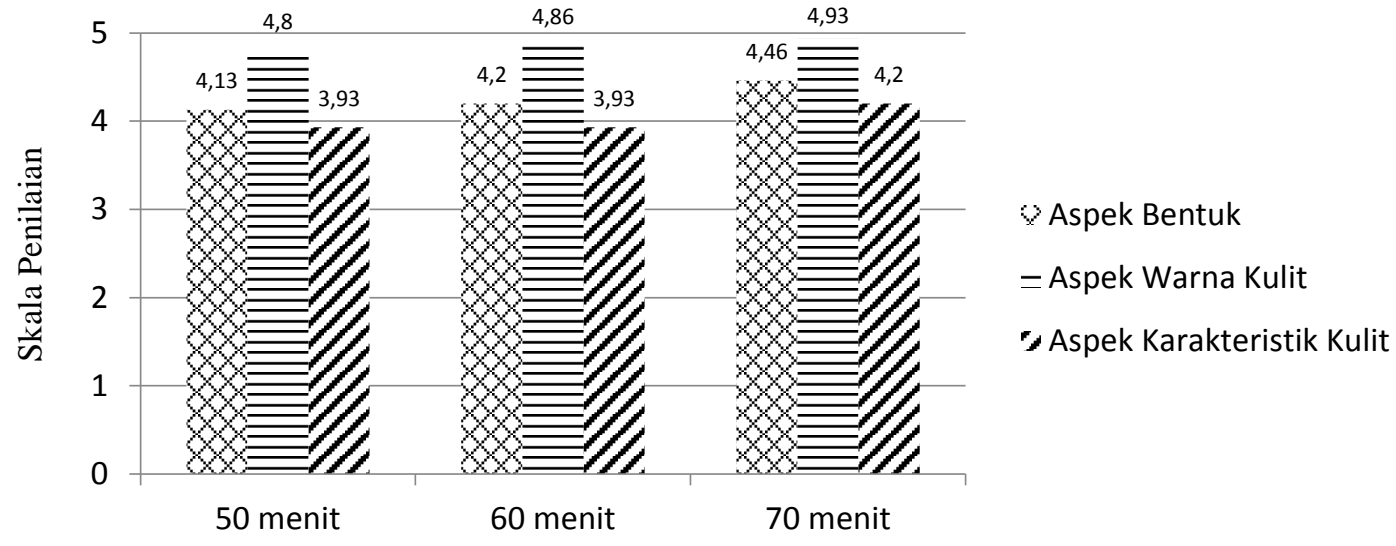

Waktu Fermentasi akhir

GAMBAR 1. Uji organoleptik Japanese Milk Bread aspek eksternal

\section{Aspek Eksternal}

Pada aspek bentuk, skala penilaian (1) adalah sangat tidak mengembang, (2) tidak mengembang, (3) agak mengembang, (4) mengembang, (5) sangat mengembang. Hasil penelitian aspek bentuk pengaruh lama waktu fermentasi akhir Japanese Milk Bread diperoleh nilai rata-rata 4,13 untuk 50 menit, 4,2 untuk 60 menit, dan 4,46 untuk 70 menit. Pada uji Kruskal Wallis pengaruh lama waktu fermentasi akhir Japanese Milk Bread pada aspek bentuk memperoleh nilai $\mathrm{x}^{2}{ }_{\text {hitung }}(2,52)<\mathrm{x}^{2}$ tabel $(5,99)$ dengan taraf signifikan $\alpha=0,05$, dan yang berarti tidak ada pengaruh lama waktu fermentasi akhir Japanese Milk Bread. Dimana perlakuan 50 menit dan 60 menit mendekati penilaian mengembang serta perlakuan 70 menit berada dalam aspek penilaian mengembang dan sangat mengembang. 
Pada aspek warna kulit, skala penilaian (1) putih kecoklatan, (2) putih pucat, (3) putih, (4) kuning keemasan, (5) putih kekuningan. Berdasarkan hasil uji kualitas pada aspek warna kulit Japanese Milk Bread nilai rata-rata pada waktu fermentasi akhir 50 menit adalah 4,8, sementara untuk nilai rata-rata waktu fermentasi akhir 60 menit adalah 4,86, dan nilai rata-rata waktu fermentasi akhir 70 menit adalah 4,93. Hasil uji Kruskal Wallis pengaruh lama waktu fermentasi akhir Japanese Milk Bread pada aspek warna kulit menyatakan bahwa tidak terdapat perbedaan nyata dengan nilai $\mathrm{x}^{2}{ }_{\text {hitung }} 0,39$, nilai signifikan $=0,05$ dan $\mathrm{x}_{\text {tabel }}^{2} 5,99$.

Skala penilaian aspek karakteristik kulit adalah (1) sangat tebal, (2) tebal, (3) agak tipis, (4) tipis, (5) sangat tipis. Pada penilaian aspek karakteristik kulit Japanese Milk Bread dengan lama waktu fermentasi akhir 50 dan 60 menit mendapat nilai rata-rata 3,93 yang artinya mendekati tipis, dan untuk lama waktu fermentasi akhir 70 menit mendapat nilai rata-rata 4,2 yang mendekati tipis karena karakteristik kulit roti yang bagus memiliki ciri-ciri tipis dan mudah untuk dirobek. Kulit roti tidak boleh tebal, keras atau liat (Syarbini, 2013). Pada uji Kruskal Wallis memperoleh nilai $\mathrm{X}^{2}{ }_{\text {hitung }} 1,78$, nilai signifikan $=0,05$ dan $\mathrm{X}_{\text {tabel }}^{2} 5,99$ yang artinya tidak ada pengaruh lama waktu fermentasi akhir Japanese Milk Bread.

\section{Aspek Internal}

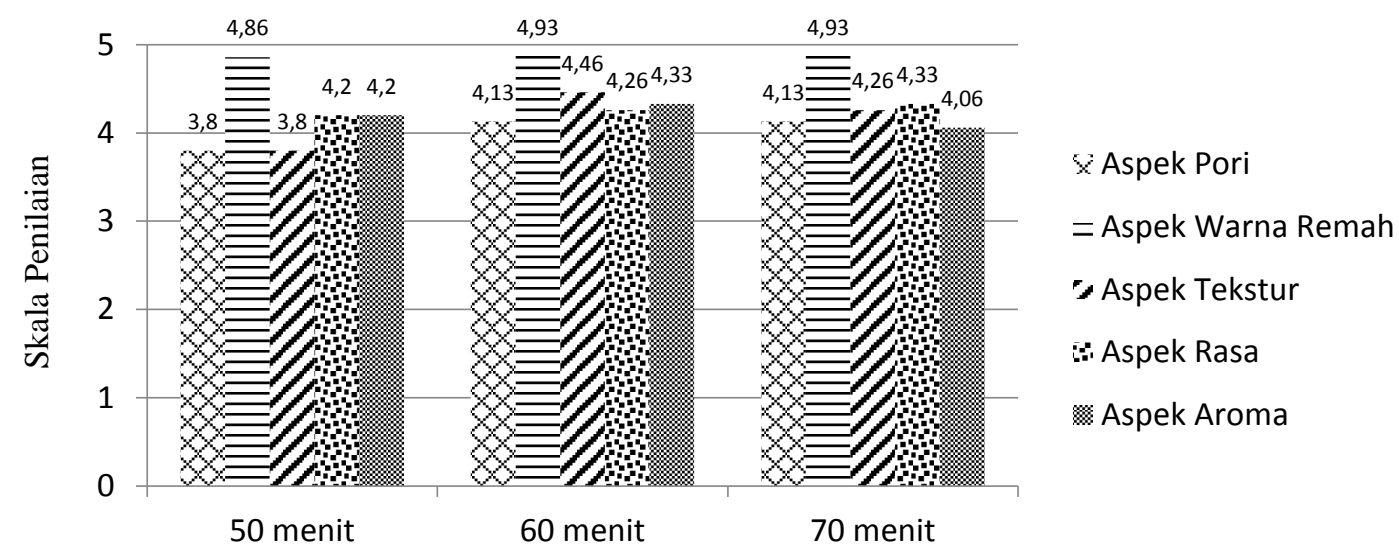

Waktu Fermentasi akhir

GAMBAR 2. Uji organoleptik Japanese Milk Bread aspek internal

Pada aspek pori, skala penilaian (1) adalah sangat kasar, (2) kasar, (3) agak kasar, (4) halus, (5) sangat halus. Penelitian aspek pori pada pengaruh lama waktu fermentasi akhir Japanese Milk Bread dengan hasil uji Kruskal Wallis tidak memiliki perbedaan yang nyata. Nilai rata- rata yang diperoleh aspek pori Japanese Milk Bread dengan lama waktu fermentasi akhir 50 menit adalah 3,8, dan nilai rata-rata fermentasi akhir 60 serta 70 menit adalah 4,13.

Pada aspek warna remah memperoleh nilai rata-rata 4,86 untuk lama waktu fermentasi akhir 50 menit; 4,93 untuk lama waktu fermentasi akhir 60 dan 70 menit. Pada uji Kruskal Wallis dapat disimpulkan bahwa tidak ada pengaruh lama waktu fermentasi akhir Japanese Milk tidak dengan nilai $\mathrm{x}^{2}$ hitung $(0,13)<\mathrm{x}^{2}$ tabel $(5,99)$. Hasil penilaian aspek warna remah pada ketiga waktu fermentasi yang berbeda berada di kategori mendekati putih kekuningan, dengan skala penilaian (1) krem, (2) kuning, (3) sangat putih, (4) putih, (5) putih kekuningan.

Pada aspek tekstur, skala penilaian (1) adalah lembut, (2) tidak lembut, (3) agak lembut, (4) lembut, (5) sangat lembut. Berdasarkan hasil uji kualitas pada aspek tekstur Japanese Milk Bread nilai ratarata pada waktu fermentasi akhir 50 menit adalah 3,8; nilai rata-rata waktu fermentasi akhir 60 menit adalah 4,46 dan 4,26 untuk waktu fermentasi akhir 70 menit. Hasil uji Kruskal Wallis pada pengaruh lama waktu fermentasi akhir Japanese Milk Bread aspek warna kulit menyatakan bahwa tidak terdapat perbedaan nyata dengan nilai $\mathrm{x}^{2}$ hitung $(4,27)<\mathrm{x}^{2}$ tabel $(5,99)$.

Menurut Beranbaum (2003) lama waktu fermentasi adalah faktor penting lain yang menentukan rasa pada roti. Hasil penelitian pada aspek rasa pengaruh lama waktu fermentasi akhir Japanese Milk 
Bread diperoleh nilai rata-rata 4,2 untuk 50 menit, 4,26 untuk 60 menit, dan pada waktu 70 menit adalah 4,33. Pada uji Kruskal Wallis pengaruh lama waktu fermentasi akhir Japanese Milk Bread pada aspek rasa memperoleh nilai $\mathrm{x}^{2}$ hitung $(0,39)<\mathrm{x}^{2}$ tabel $(5,99)$ dengan taraf signifikan $\alpha=0,05$, dan yang berarti tidak ada pengaruh lama waktu fermentasi akhir Japanese Milk Bread, dan rasa Japanese Milk Bread pada ketiga waktu fermentasi akhir 50, 60, dan 70 menit mendekati terasa susu dengan kategori penilaian (1) sangat tidak terasa susu, (2) tidak terasa susu, (3) agak terasa susu, (4) terasa susu, (5) sangat terasa susu.

Pada aspek aroma, kategori penilaian (1) adalah sangat tidak beraroma butter, (2) tidak beraroma butter, (3) agak beraroma butter, (4) beraroma butter, (5) sangat beraroma butter. Hasil penelitian untuk aspek aroma pada pengaruh lama waktu fermentasi akhir Japanese Milk Bread dengan hasil uji Kruskal Wallis tidak memiliki perbedaan yang nyata dengan $\mathrm{x}^{2}$ hitung $(1,56)<\mathrm{x}^{2}$ tabel $(5,99)$. Nilai ratarata yang diperoleh aspek aroma Japanese Milk Bread dengan lama waktu fermentasi akhir 50 menit adalah 4,2; 4,33 untuk lama waktu fermentasi akhir 60 menit dan 4,06 untuk lama waktu fermentasi akhir 70 menit. Pada waktu fermentasi akhir 50 dan 70 menit berada pada penilaian mendekati beraroma butter, sedangkan waktu fermentasi akhir 60 menit berada diantara beraroma butter dan sangat beraroma butter. Hal ini dikarenakan penggunaan mentega karena mentega merupakan shortening terbaik dengan rasa yang sangat lezat dan mengandung lemak lebih tinggi sehingga menghasilkan aroma yang baik (Chan, 2008).

\section{Uji Kualitas Fisik}
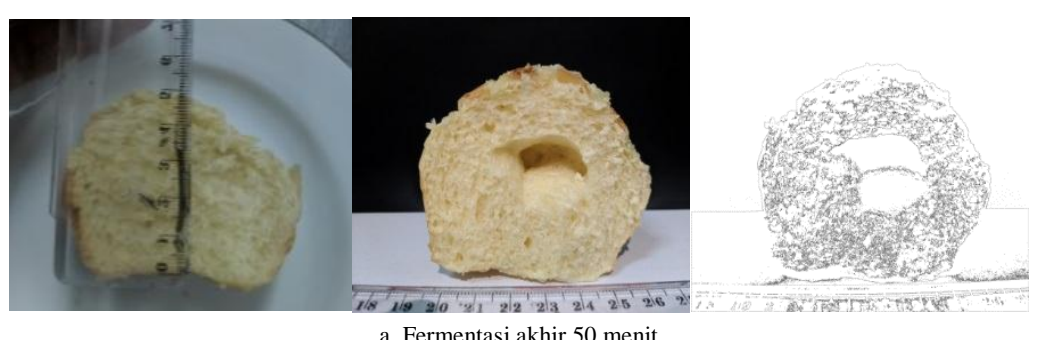

a. Fermentasi akhir 50 menit
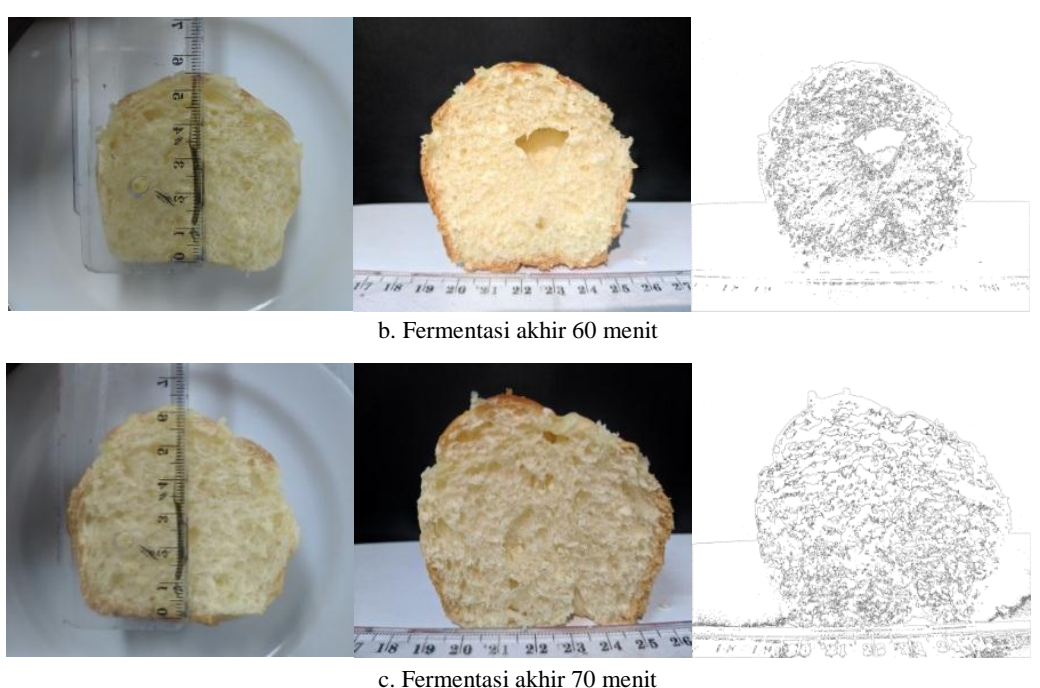

c. Fermentasi akhir 70 menit

GAMBAR 3. Uji kualitas fisik Japanese Milk Bread dengan lama waktu fermentasi akhir 50, 60, dan 70 menit

Uji kualitas fisik pada Japanese Milk Bread terdiri dari dua uji yaitu uji dimensi tinggi dan uji pori. Gambar 3 menunjukkan hasil uji fisik Japanese Milk Bread dengan lama waktu fermentasi akhir 50, 60, dan 70 menit. Menurut Peighambardoust dkk (2010) fermentasi adalah proses kunci lain dari produksi roti, di mana aktivitas ragi dan waktu fermentasi menentukan jumlah gas yang diproduksi dan tingkat ekspansi adonan. Pada dimensi tinggi diketahui bahwa final proofing 50 menit senilai $5 \mathrm{~cm}$; $5,5 \mathrm{~cm}$ untuk final proofing 60 menit; dan $6 \mathrm{~cm}$ pada final proofing 70 menit. Pada bagian pori semua waktu fermentasi akhirnya memiliki pori yang kecil serta halus. Perbedaanya terletak pada ruang udara 
yang ada didalam roti. Semakin lama waktu fementasinya maka ruang udara semakin mengecil seperti waktu fermentasi akhir 50 menit memiliki lebar ruang udara $2 \mathrm{~cm}, 1 \mathrm{~cm}$ ruang udara pada fermentasi akhir 60 menit, dan fermentasi akhir 70 menit tidak memiliki ruang udara sehingga terlihat padat pada bagian dalam roti.

\section{KESIMPULAN}

Hasil uji Kruskal Wallis pada penilaian organoleptik menunjukkan bahwa tidak ada pengaruh lama waktu fermentasi akhir Japanese Milk Bread dengan lama waktu 50, 60, dan 70 menit pada aspek bentuk, warna kulit, karakteristik kulit, pori, warna remah, tekstur, rasa, dan aroma. Tetapi pada penilaian analisis fisik untuk tinggi serta pori pada ketiga Japanese Milk Bread menunjukkan perbedaan dan berdasarkan analisis fisik tinggi diketahui bahwa nilai tertinggi pada waktu fermentasi akhir 70 menit adalah $6 \mathrm{~cm}$, dan nilai terkecil adalah $5 \mathrm{~cm}$ pada fermentasi akhir 50 menit. Penilaian pori tidak menghasilkan perbedaan yang nyata, semua waktu fermentasi akhir menghasilkan pori yang halus dan kecil akan tetapi roti pada fermentasi akhir 50 menit memiliki ruang udara terlebar yaitu 2 $\mathrm{cm}$,dan tidak memiliki ruang udara pada fermentasi akhir 70 menit yang menghasilkan roti yang terlihat padat pada bagian dalam dan tetap memiliki pori yang kecil serta halus.

Berdasarkan data di atas menunjukkan bahwa lama waktu fermentasi akhir (final proofing) tidak mempengaruhi kualitas Japanese Milk Bread secara signifikan. Namun dilihat pada penilaian analisis fisik (tinggi dan pori) lama waktu fermentasi akhir 70 menit dapat direkomendasikan untuk membuat Japanese Milk Bread.

\section{REFERENSI}

Baardseth P, Kvaal K, Lea P, Ellekjaer MR, Farrgestad EM. 2000. The effects of bread making process and wheat quality on French baguettes. J Cereal Sci 32:73-87

Beranbaum, Rose Levy, 2003. The Bread Bible. New York : The Maple-Vail Book Manufacturing Group.

Chan, Levi Adhitya. 2008. Paduan Wirausaha Roti Modern. Jakarta: PT. AgroMedia Pustaka

Syarbini, Husin. (2013). A-Z Bakery. Jakarta: PT Tiga Serangkai Pustaka Mandiri

Peighambardoust, S.H., Fallah, E., Hamer, R.J. \& van der Goot, A.J. 2010. Aeration of bread dough influenced by different wayof processing. Jurnal of Cereal Science, 51, 89-95.

Mohamed, Hasbullah, Kamis, dkk. 2018. The Innovation of Steamed Bun (Pau) Using Water Roux: Bakery Students Acceptance. Jurnal. Malaysia: Universiti Pendidikan Sultan Idris

Cahyana, Cucu dan Artanti, Guspri Devi. 2015. Bahan Dan Fungsi Bahan Dalam Pembuatan Roti. Jakarta: UNJ

Syarbini, Husin. (2016, 15 September). Bagi Yang Suka Bikin Roti, Namun Belum Tahu Cara Menilai Kualitas Roti. Artikel Ini Bisa Membantu Anda! . Diakses 5 Juli 2019, dari http://usahabakery.com/cara-menilai-kualitas-roti 